\title{
The Impact of Pension Funds' Investments on the Capital Market-The Case of Lusaka Securities Exchange
}

\author{
Nsama Musawa, Clement Mwaanga \\ Department of Business Studies, Mulungushi University, Kabwe, Zambia \\ Email: nsama.musawa@yahoo.com,nnjebele@mu.ac.zm,cmwaanga@mu.ac.zm,mwaanga.clement@yahoo.co.uk
}

How to cite this paper: Musawa, N. and Mwaanga, C. (2017) The Impact of Pension Funds' Investments on the Capital Market-The Case of Lusaka Securities Exchange. American Journal of Industrial and Business Management, 7, 1120-1127. https://doi.org/10.4236/ajibm.2017.710080

Received: August 3, 2017

Accepted: October 8, 2017

Published: October 11, 2017

Copyright $\odot 2017$ by authors and Scientific Research Publishing Inc. This work is licensed under the Creative Commons Attribution-NonCommercial International License (CC BY-NC 4.0). http://creativecommons.org/licenses/by-nc/4.0/ (c) (i) \& Open Access

\begin{abstract}
The Lusaka Securities exchange (LuSE) is one of the developing stock markets in Africa. As of 2015 it had only 22 listed companies with the market capitalization of about 5849 million dollars. There are a number of sectors that contribute to the growth of the stock market in Zambia. This study focused on the insurance sector, the pension funds mobilized contributions from the working population and invested in various assets among them is equity. According to the pension scheme investment guidelines (2011), pension funds are mandated to invest not less than $5 \%$ but not more than $70 \%$ of their total investment in equity. Hence, one would expect pension funds to have a good effect on the Zambian capital market. However the impact cannot be conclusive without undertaking a study to assess the effect of pension funds and capital market. Therefore, this study was an attempt to investigate the long run effect of pension fund's investment on the Lusaka securities exchange performance. The study used quarterly data for the period ranging from January 2009 to December 2015, and employed the cointegration and Vector Error Correction; the results prove the existence of long run relationships between the pension funds and the market capitalization. This relationship implies that if pension funds are encouraged to invest more in equity, it will contribute to the growth of capital market, hence developing. Recommendations have been made to policy markers on how they can use the sector to improve the performance of the capital market.
\end{abstract}

\section{Keywords}

Stock Market Capitalization, Pension Fund Investments, Cointergration

\section{Introduction}

The Lusaka Securities exchange is one of the developing stock markets in Africa. 
Although ranked as one of the top ten active stock markets in Africa in 2014 (Africa Business central, 2014) [1], it has only 22 listed companies with the market capitalization of about $\$ 5849$ million as of 2015 , hence the need for this market's development cannot be overemphasized. One of the sectors that can enhance the performance of the stock market is the pension funds. Literature has shown that pension funds can influence financial development because they are mobilizing pension contributions from the working population and invest in various assets among them is equity (Meng, and Pfau, 2010) [2]. Zambia has seen the growth of the pension fund industry from 207 registered pension funds in 2005 to 239 in 2015. According to the pension scheme investment guidelines (2011), pension funds are mandated to invest not less than $5 \%$ but not more that $70 \%$ of their total investment in equity. Hence, pension funds should have a good effect on the one Zambian capital market. However the impact cannot be conclusive because little or no studies have been done to assess it. Various studies have explored the relationship between pension funds and capital market. However, these studies have focused mainly on developed countries and emerging markets (Catalan, Impavido \& Musalem, 2000 [3]; Impavido, Musalem and Tressel, 2003 [4] and Meng \& Pfau, 2010 [2]). Although Limited country case studies have been done on emerging markets (Thom, 2014) [5], little is known about Zambia, hence the need for this study. The main purpose of this research was to investigate the long run effects of pension fund's investment on the Lusaka securities exchange performance. In the process, the study provided the guide to policy makers on how they can use the insurance sector to contribute to the growth of the Zambian stock market

\section{Literature Review}

Among of the studies to examine the relationship between pension funds and financial market is $\mathrm{Hu}$ (2005) [6]. In this study, Panel Correction Model and Panel Granger causality was used to test for 10 Asian countries covering a period of 7 years (2002 to 2008), the study found that pension funds growth contributes to financial development. Hu (2005) [6] measured stock market performance using stock market capitalization, stock market total value traded and stock market turnover all a percentage of GDP. The pension fund was measured by the fund assets using quarterly data from 1985 to 2013.

Meng, and Pfau (2010) [2] investigated the impacts of pension funds on capital market development, for the overall sample of 32 developed and emerging market countries. Using yearly panel data per country, they found that pension fund financial assets have positive impacts on stock market.

Later on a study by Thom (2014) [5] applied the Johansen cointegration approach to evaluate the impact of pension funds on the growth of the South African stock market. Stock market development was measured using market capitalization, liquidity and volatility. The study findings revealed that South African pension funds have improved the liquidity and reduced the volatility of the stock 
market.

Furthermore, Melok and Ikhide (2014) [7] used autoregressive distribution lag (ARDL) and the vector error correction model (VECM) to establish that there was a positive relationship between pension savings and stock market development. However they found no long-run relationship between pension savings and the bond market development. The pension fund was measured using total assets of direct investments in debt instruments for private bond market and for public debt while Stock market capitalization as a percentage of GDP was used as a proxy for capital market development. The data was from 1975-2012.

Using a sample of ten Central and Eastern European countries and the period 2001-2010, Enache et al. (2015) [8] investigated the interaction between pension reform and capital market development. The results confirmed the existence of a strong positive short-term effect, and a lower magnitude positive long-term effect of the pension funds' assets on the market capitalization.

A recent study conducted by Zubair (2016) [9] examined the impact of pension fund investments on the performance of capital market in Nigeria. The study was a time series analysis covering a period from 2009 to 2016 using the Autoregressive Integrated Moving Average (ARIMA) regression technique. The study results confirmed the existence of a positive relationship between pension funds' investments and the performance of capital market in Nigeria. Specifically, the study concludes that total pension investments in Nigeria improved the performance of the Nigerian capital market significantly in terms of depth and liquidity (market capitalization and value traded). Capital market performance variables were measured by market capitalization and total value traded; while pension funds investment was measured using the total pension funds assets at the end of every quarter.

Bayar (2016) [10] also, examined the effect of individual pension funds on the development of capital market in Turkey. The used a sample of period of ten years. To analyse the data they used cointegration test. The study found that, in the long run pension funds should have a positive impact on the capital market. Capital market performance variables were measured by market capitalization and total value traded, while Pension funds' investment was measured using the total pension funds assets.

\section{Data and Methodology}

This study employed Vector Auto Regression (VAR) based cointegration test methodology by Johansen (1996) [11] to analyze the long run effect of the pension fund's investment on the stock market performance. Most studies have used market capitalization and pension assets as a percentage of GDP. These focused on assessing the impact on stock market development (Thom (2014) [5], Meng, and Pfau (2010) [2]). However since this study like similar studies ( $\mathrm{Zu}-$ bair (2016) [9], Bayar (2016) [10]), focused on stock market performance and 
not development, pension fund's investment was used and measured by the total fund investment which represents assets bought by the pension fund with the contributions made by members. Stock market performance was measured by market capitalization found by multiplying the stock price by the total number of shares outstanding. Table 1 gives a summary of how the variables were measured.

This study employed quarterly data ranging from January 2009 to December 2015 , covering a period of 7 years. The data on total fund's investment were collected from the Zambia Pensions and Insurance Authority annual report, while the data on the stock market data was collected from the Lusaka Stock Exchange (LuSE). Data analysis followed four steps: 1) Graphical analysis, 2) Diagnostic tests for the variables, 3) Lag length selection and 4) cointegration test.

\section{Results}

This section shows how graphical analysis and econometric models were used to analyse the data on the LuSE Market Capitalization and total funds Investment The graphic analysis compares the dependent variable LuSE market performance measured by market capitalization and the independent variables Pension fund's investment.

\subsection{Graphical Analysis}

A graphical analysis of the data on LuSE market capitalization and pension's investment is shown in Figure 1 below. The market capitalization and pension investment show an upward trend. They all move around the non Zero or constant meaning, the variables might not be stationary. As can be observed from the graph the two variables move in the same direction which shows that they have a positive relationship. This is also confirmed by correlation of 0.86 between the two variables.

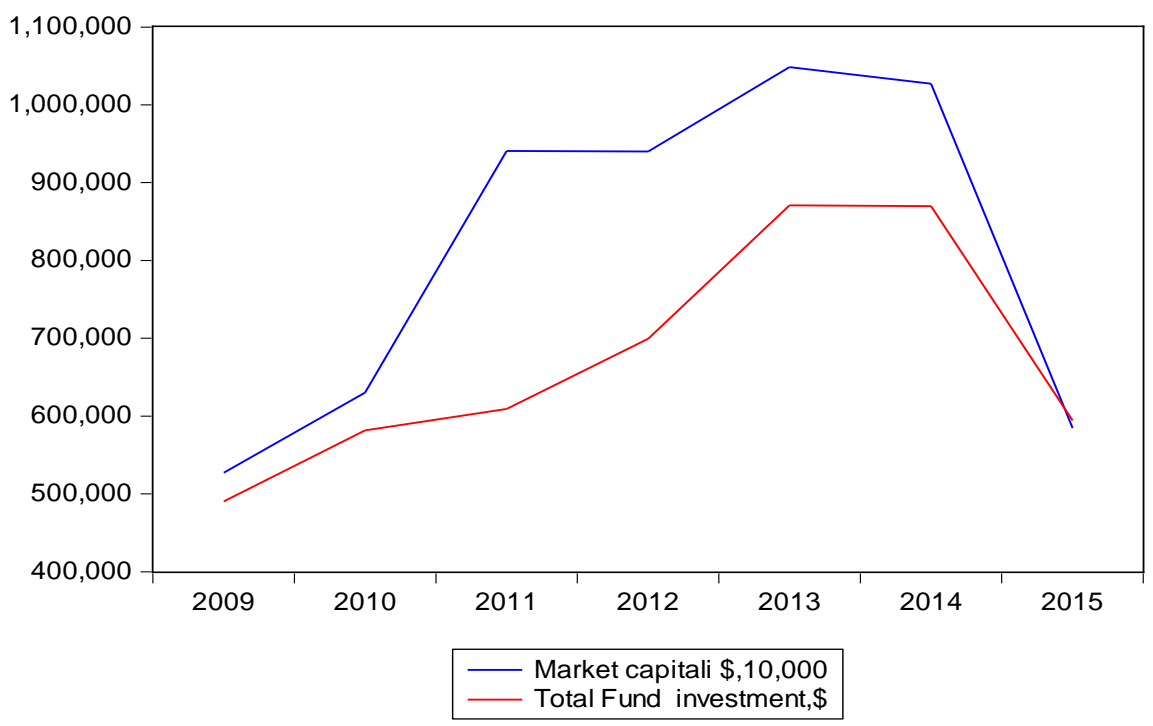

Figure 1. Market capitalision and pension fund. 
Table 1. Measurement of variables.

\begin{tabular}{cc}
\hline & Measurement of Variables \\
\hline Independent Variable & Pension fund (contribution made by members) \\
Dependent Variable & Stock market performance ( market capitalization) \\
\hline
\end{tabular}

Source: Authors synthesis of the literature.

\subsection{Econometric Modelling}

Similar research on this subject have used Vector Auto regression (VAR) based cointegration test methodology by Johansen (1996) [11] to analyse the effect of pension fund's investment on the capital markets (Thom, 2014 [5]; Melok \& Ikhide, 2014 [7]; Zubair, 2016 [9]; Bayar, 2016 [10]). This study replicated the same Vector Auto regression (VAR) based cointegration test methodology by Johansen (1996) [11] to analyse the effect of pension fund's investment on the market capitalization.

\subsubsection{Diagnostic Tests}

Before the estimation was done some diagnostic test were done among them was the normality test for the dependent variable and the Unit root test.

\section{Normality of dependent variable}

One of the assumptions in regression is that the dependent variable is normally distributed. This test was done using Jarque-Bera statistics. If the Jarque-Bera probability test is non-significant $(p>0.05)$, it tells that the distribution is normally distribution (Field, 2005) [12]. The Jarque-Bera statist of 2.2078 with the probability of 0.03315 was observed, indicating that the market capitalization was normally distributed.

\section{Unit root test}

The unit root test was the first to be done before the cointegration test, the unit root test was performed to confirm the stationary properties of the data so as to know the order of integration of the variables into the long run equation.

The results of the unit root tests based on the Augmented Dickey-Fuller (ADF) tests are presented in Table 2.

If the data is stationary (has no unit root) the $t$ value, should be greater than the critical values in absolute terms and the $\mathrm{p}$ value should be significant (less than 0.05) The results show that, the Market Capitalization was not stationary because the ADF statistic ( $\mathrm{t} \alpha$ ) 0.8173 is not greater than the critical values of $4.3393,3.5875$ and 3.2292 at all the levels of significant (1\%,5\% and 10\%) and the $\mathrm{P}$ value of 0.9513 is not significant, but after the first differencing it becomes stationary as $(\mathrm{t} \alpha) 5.4614$ is greater than all the critical values of $4.3393,3.5875$ and 3.2292 at all levels of significance and the p value of 0.0008 is significant thus integrated of the order one I (1).

The Pension Fund investment found not to be stationary (had a unit root) because the ADF statistic ( $\mathrm{t} \alpha$ ) 0.87093 is not greater than the critical values of $4.3393,3.5875$ and 3.2292 at all the levels of significant (1\%,5\% and $10 \%)$ and the $P$ value of 0.9451 is not significant, but after the first differencing it becomes 
Table 2. Summary of ADF unit root test results.

\begin{tabular}{cccccc}
\hline \multirow{2}{*}{ Description } & \multicolumn{4}{c}{ Differencing } & \multirow{2}{*}{ Order of } \\
\cline { 2 - 5 } & \multicolumn{2}{c}{ Levels } & \multicolumn{2}{c}{ First Difference } & Integration \\
\cline { 2 - 5 } & $t$-Value & $P$-Value & $t$-Value & $P$-Value & \\
\hline LuSE Market Cap & -0.8173 & 0.9513 & -5.4614 & 0.0008 & $\mathrm{I}(1)$ \\
Pension Fund investment & -0.8709 & 0.9451 & -5.2361 & 0.0014 & $\mathrm{I}(1)$ \\
& & & $1 \%$ level & -4.3393 & -4.3506 \\
& & & $5 \%$ level & -3.5875 & -3.5950 \\
& & & $10 \%$ level & -3.2292 & -3.2334 \\
\hline
\end{tabular}

Source: Generated by the authors (2017).

stationary use ( $\mathrm{t} \alpha)-5.2361$ is greater than all the critical values of $4.3393,3.5875$ and 3.2292 at all levels of significance and the p value of 0.0014 is significant so it was integrated of the order one I (1).

\subsubsection{Long Run Estimation Based on Cointegration Analysis}

Since the variables were found to be stationery after the first difference, a cointegration test was performed in order to test whether the variables were cointegrated or not. The presence of a cointegrating relationship means that the variables have a long run equilibrium relationship and therefore forms a basis for the Vector Error Correction specification. To do this, the first step was the Lag length selection and the second was a cointegration test and third was Vector Error Correction specification.

\section{1) Lag length selection}

In the first step of establishing the lag length unrestricted Vector Auto Regression estimation was undertaken in order to come up with an appropriate lag length to be used when establishing cointegration among the variables. A lag length of four was selected as an appropriate based on the sequential modified LR test statistic, Final predictor error, Akaike information criteria and HannanQuin information criteria all of Eviews 7.

\section{2) Cointegration test}

The Johansson Cointegration test was done for the Stock market capitalization dependent variable and pension fund investment as independent variables. A cointegration exists if the trace statist value is more than the critical value. The results for Johansson cointegration test in Table 3 shows that there is cointegration as trace statist value of 5.7561 is more than the critical value of 3.8414 and the probability value of 0.016 is significant. This indicates that there is a long run relationship between stock market capitalization and pension fund investment. This result is Similar to other studies conducted in this regard (Meng \& Pfau, 2010 [2]: Thom, 2014 [5]: Moleko \& Ikhide, 2014 [7]: Bayar, 2016 [10]).

Since the variables have a long rung relationship. The long run cointegrating equation was estimated using Vector Error Correction and the results is presented in Table 4. 
Table 3. Cointegration rank trace test analysis results.

\begin{tabular}{cccccc}
\hline $\begin{array}{c}\text { Cointegrated } \\
\text { variable }\end{array}$ & $\begin{array}{c}\text { Hypothesized } \\
\text { No. of CE }(\mathrm{s})\end{array}$ & Eigevalue & $\begin{array}{c}\text { Trace } \\
\text { Statistic }\end{array}$ & $\begin{array}{c}0.5 \\
\text { Critical Value }\end{array}$ & Prob \\
\hline Market Cap Investment & At most 1 & 0.2214 & 5.7561 & 3.8414 & 0.0164 \\
\hline
\end{tabular}

Table 4. VEC cointegration equation results.

\begin{tabular}{cc}
\hline Cointegrating Equation & Coint Equation (1) \\
\hline MC & 1.000000 \\
INV & -9.268776 \\
C & -542008.6 \\
\hline
\end{tabular}

$$
\mathrm{MC}=542008.6+9.2687 \mathrm{INV}+\mathrm{E}
$$

where MC: The market capitalization

INV: Pension fund's investment

E: Error term

From the equation, it was observed that that holding pension Investment to a constant zero, Market Capitalization will be 542,008.6 thousand US dollars. A unit increase in Investment will lead to an increase in Market Capitalization by 9.2687 units. This result is comparable to Meng and Pfau (2010) [2] and Thom (2014) [5].

\section{Conclusion}

This research investigated the effect of pension funds investment on the Stock market performance in Zambia. By employing the cointegration and Vector Error Correction, the results indicate that there is a long run relationship between the pension funds and the market capitalization. This relationship means that if pension funds invest more in equity, it will contribute to the growth of Lusaka Stock exchange. This recommendation is in line with the pension scheme investment guidelines (2011), whose requirement is for pension funds to invest up to $70 \%$ of their total investment in equity; currently pension funds contribute an average of $24 \%$ of the total fund's assets.

\section{References}

[1] http://www.africanbusinesscentral.com/2015/01/30/the-top-10-most-active-stock-m arkets-in-africa-in-2014-infographic/

[2] Meng, C. and Pfau, W.D. (2010) The Role of Pension Funds in Capital Market Development. National Graduate Institute for Policy Studies, Minato, Tokyo, 1-20.

[3] Catalan, M., Impavido, G. and Musalem, A. (2000) Contractual Savings or Stock Market Development: Which Leads? Journal of Applied Social Studies, 120, 445-487.

[4] Impavido, C., Musalem, A. and Tressel, T. (2003) The Impact of Contractual Savings Institutions in Securities Markets. World Bank Policy Research Paper, No. 2948, The World Bank, Washington DC, 1-28. 
[5] Thom, A.M. (2014) Impact of Pension Funds on Stock Market Development in South Africa and Policy Implications. Doctoral Dissertation, Stellenbosch University, Stellenbosch.

[6] Hu, Y. (2005) Pension Reform, Economic Growth and Financial Development-An Empirical Study. Economics and Finance Working Paper No 05-05, Brunel University.

[7] Moleko, N. and Ikhide, S. (2016) Pension Funds Evolution, Reforms and Trends in South Africa. Discussion Paper PI-1608. Pensions Institute.

[8] Enache, C., Milos, R.C. and Milos, M.C. (2015) Pension Reform and Capital Market Development in Central and Eastern European Countries. Economic ResearchEkonomska Istrazivanja, Taylor Francis Group, 21, 75-84.

[9] Zubair, A.K. (2016) Effects of Pension Funds' Investments on Capital Market Performance in Nigeria. International Journal of Economics and Business Management, 2, No. 9

[10] Bayar, Y. (2016) Individual Pension Funds and Capital Market Development in Turkey. Review of Economic and Business Studies, 9, 95-109.

https://doi.org/10.1515/rebs-2016-0036

[11] Johansen, S. (1996) Likelihood Based Inference in Cointegrated Vector Autoregressive Models. Oxford University Press, Oxford.

[12] Field, A. (2005) Discovering Statistics Using SPSS. SAGE Publication, London. 